\title{
Pengawasan Mutu Ternyata Dimulai dari Tingkat Sel
}

\author{
Fajar Ramadhitya Putera \\ Kementrian Kesehatan Republik Indonesia, Jakarta \\ email: fajariyoo@yahoo.com \\ (Submit 30/5/2019, Revisi 14/7/2019, Diterima 15/7/2019)
}

\begin{abstract}
Abstrak
Farmasi adalah dunia di mana mutu menempati posisi yang sangat penting. Mutu yang tidak sesuai persyaratan dapat berisiko merugikan kesehatan atau bahkan mengakibatkan kematian. Pengawasan mutu merupakan bagian penting yang tidak dapat terpisahkan bagi industri farmasi, baik obat, obat tradisional, kosmetika, maupun makanan. Pengawasan mutu meliputi pengetahuan tentang penanganan sediaan farmasi mulai dari bahan baku hingga pemantauan produk setelah diedarkan di masyarakat. Dalam artikel komentar ini dibahas terkait pengawasan mutu yang berawal dari tingkat sel.
\end{abstract}

Kata kunci : pengawasan mutu, industri farmasi, sel

\section{Outline}

- Pendahuluan

- Pentingnya pengawasan mutu

- Sejarah perkembangan konsep mutu

- Dimulai dari Sel

- Kesimpulan

- Daftar Pustaka

\section{Pendahuluan}

Farmasi adalah dunia di mana mutu menempati posisi yang sangat penting. Mutu yang tidak sesuai persyaratan dapat berisiko merugikan kesehatan atau bahkan mengakibatkan kematian.

\section{Pentingnya pengawasan mutu}

Masih lekat dalam ingatan, insiden-insiden ketika mutu sediaan farmasi dipertanyakan. Kasus obat anastesi yang melibatkan perusahaan farmasi besar dan rumah sakit internasional, juga kasus vaksin palsu serta penyalahgunaan obat keras.

Kita bertanya-tanya, mengapa sistem produksi dan distribusi di jalur resmi dapat tersusupi produk yang tidak memenuhi persyaratan mutu? Apakah terdapat hubungan yang erat antara mutu dan keamanan produk? Bagaimana produsen (dan konsumen) memaknai konsep mutu? 
Persepsi konsumen yang beragam tentang konsep produk memberikan definisi yang luas mengenai mutu. Secara umum, mutu merupakan sekumpulan karakteristik yang melekat pada produk, suatu parameter bagi konsumen dalam menentukan keberterimaan produk.

\section{Sejarah perkembangan konsep mutu}

Perkembangan konsep mutu menjalani lima tahap sebagai berikut. Tahap pertama adalah era tanpa mutu, ketika mutu belum menjadi perhatian dalam pembuatan suatu produk. Konsumen terpaksa mengonsumsi produk yang ada meski pun mutunya buruk karena tidak ada penyedia lain.

Tahap kedua dimulai sekitar tahun 1800-an, sebelum dipasarkan, produk akhir diinspeksi. Tahap ketiga, mutu dikendalikan secara statistik untuk mendeteksi penyimpangan pada produk yang diproduksi. Tahap keempat berkembang pada tahun 1950-an, yakni era jaminan mutu yang meyakini bahwa upaya mencegah kerusakan lebih baik daripada upaya memperbaiki cacat yang terjadi. Tahap kelima, dikenal sebagai Manajemen Mutu Total, sistem manajemen strategis yang melibatkan semua stakeholder untuk memperbaiki proses secara berkesinambungan.

Pengawasan mutu merupakan bagian penting yang tidak dapat terpisahkan bagi industri farmasi, baik obat, obat tradisional, kosmetika, maupun makanan. Pengawasan mutu meliputi pengetahuan tentang penanganan sediaan farmasi mulai dari bahan baku hingga pemantauan produk setelah diedarkan di masyarakat.

\section{Dimulai dari Sel}

Pengawasan mutu jamak diimplementasikan di industri, namun siapa sangka pengawasan mutu juga terjadi di dalam tubuh kita, yakni di tingkat sel, satuan terkecil makhluk hidup. Para ilmuwan mengidentifikasi mekanisme pengawasan seluler yang berperan dalam pengawasan mutu ekspresi gen.

Sel harus mencegah terjadinya ekpresi protein yang menyimpang dan berbahaya. Terdapat dua protein asam ribonukleat yang bertindak sebagai pengendali utama untuk memastikan kelayakan suatu ekspresi gen, demikian menurut Professor Heike Krebber dari Universitas Göttingen, Jerman.

Protein Gbp2 and Hrb1 berperan penting dalam proses translasi atau penerjemahan informasi genetik (DNA) ke messenger RNA (mRNA). Kesalahan yang terjadi selama proses ini berisiko memicu pembentukan sel kanker dan penyakit neurodegeneratif.

Pada organisme seperti tumbuhan dan hewan, proses transkripsi terjadi dalam inti sel (nukleus), sedangkan proses translasi berlangsung di cairan sel (sitoplasma). Dalam proses ekspresi informasi genetik organisme, DNA ditranslasikan ke mRNA dalam inti sel. mRNA ini lalu bermigrasi ke dalam cairan sel yang mengelilingi inti sel, untuk kemudian dikonversi menjadi protein. 
mRNA tak dapat meninggalkan inti sel kecuali proses ini berjalan dengan tepat dan mRNA dilepaskan oleh intron (bagian dari rangkaian gen yang bersifat non coding). Mekanisme ini adalah satu-satunya cara untuk mengurangi kesalahan dalam transportasi informasi genetik.

Protein Gbp2 dan Hrb1 sepertinya mengawasi proses translasi di dalam inti sel. Tidak aktifnya dua protein ini mengarah pada akumulasi kerusakan mRNA dalam jumlah signifikan di cairan sel. Jika penyimpangan terjadi selama translasi, misalnya jika sekuens intron tidak dipindahkan, Gbp2 dan Hrb1 memastikan bahwa mRNA yang rusak diputuskan. Sebaliknya, ketika translasi berjalan baik, dua protein tersebut memastikan bahwa mRNA yang layak dipindahkan dari inti sel ke cairan sel.

Pembagian ruang pada sel eukariot menjadi inti sel dan cairan sel mengharuskan pergerakan protein dan RNA melewati inti sel. Harus dipastikan bahwa intron yang mengandung pre messenger RNAs ditahan di inti sel sampai proses selesai. Hanya mRNAs yang telah diproses secara penuh yang dapat ditransportasikan ke dalam cairan sel dan diterjemahkan di ribosom.

\section{Kesimpulan}

Mutu yang tidak sesuai persyaratan dalam sediaan farmasi dapat berisiko merugikan kesehatan atau bahkan mengakibatkan kematian. pengawasan mutu juga terjadi di dalam tubuh manusia, yakni di tingkat sel, satuan terkecil makhluk hidup. Para ilmuwan mengidentifikasi mekanisme pengawasan seluler yang berperan dalam pengawasan mutu ekspresi gen. Mungkin demikian cara alam mengajari manusia bahwa rangkaian pengawasan mutu sebaiknya dimulai dari tahap yang paling kecil, yakni di tingkat sel.

\section{Daftar Pustaka}

Hackmann, A., H. Wu, U.-M. Schneider, K. Meyer, K. Jung, and H. Krebber, Quality control of spliced mRNAs requires the shuttling SR proteins Gbp2 and Hrb1. Nature Communications, 5, 3123 (2014). DOI: 10.1038/ncomms4123

PLukong, K. E., Chang, K. W., Khandjian, E. W. \& Richard, S. RNA-binding proteins in human genetic disease. Trends Genet. 24, 416-425 (2008).

Fasken, M. B. \& Corbett, A. H. Mechanisms of nuclear mRNA quality control. RNA. Biol. 6, 237-241 (2009).

Muller-McNicoll, M. \& Neugebauer, K. M. How cells get the message: dynamic assembly and function of mRNA-protein complexes. Nat. Rev. Genet. 14, 275-287 (2013). 